\title{
Role-play in Literature Lectures
}

\author{
Isobel Ní Riain, Ciarán Dawson and Marian McCarthy
}

\begin{abstract}
The following article draws on research that I carried out as part of a master's degree in Teaching and Learning in Higher Education in University College Cork (UCC) between 2015-2016. I teach Irish language and literature in the Modern Irish Dept. of UCC. The intervention I used with my students was role-play which is not generally used in the teaching of Irish Literature. My research was an investigation into the learning students associate with the use of role-play in literature lectures. The findings show that while students reported learning many different things from role-play, there was no consensus as to what one could learn from the use of role-play in literature lectures. I am encouraged by the findings and will continue to use role-play in the future. ${ }^{1}$
\end{abstract}

\section{Introduction}

In 2015, I introduced role-play to my Irish language literature lectures. The module in question was GA2019 (Cineálacha Scéalaíochta: An Litríocht Bhéil agus an Gearrscéal Liteartha - which translates to: Types of Storytelling Oral Literature and the Literary Short Story). This module is concerned with analysing folkloric storytelling and modern short stories. In some cases the story at the centre of the role-play was in English but the role-play was in Irish and in other cases the story and the role-play were in Irish. My class for the module GA2019 consisted of 18 students ( 3 young men and 15 young women). They were taking Irish either as one of their two subjects for the BA degree or as part of a Commerce degree or as the sole subject for a Higher Diploma in Irish. The majority of the students were hoping to become teachers. Role-play is not generally used in literature lectures in the Irish language field. There seems to be a good deal of fear on the part of Irish language lecturers relating to the use of role-play: fear that the students simply will not co-operate or that the lecturers themselves will not be able to introduce role-play successfully. Role-play is seen more as an activity to be used in language classes if used at

\footnotetext{
${ }^{1}$ Dr. Isobel Ní Riain carried out this research as part of a master's degree in Teaching in Learning in Higher Education in University College Cork (2015-2016). Her thesis was supervised by Dr. Ciarán Dawson and the lecturer delivering the course was Dr. Marian McCarthy.
} 
all. I had been using role-play in the context of language labs when I attended a symposium on Performative Teaching and Learning organised by the UCC German Dept in 2013. This event and the ensuing Scenario Forum Conference in 2014 motivated me to try using role-play in literature lectures. My research question was: What learning do students associate with role-play? I wanted to listen to the student voice. I felt sure that students would learn new things from doing role-play. I predicted that their understanding of the stories would increase as a result of doing role-play.

\section{Theoretical Framework}

As part of my reading for this piece of research I drew on theory from education, drama education, teaching and learning and performative teaching and learning.

Certain types of reading seems to be going out of fashion among university students. They are now more likely to spend time on a "visualised world" (Schewe 2004: 82). It is true that students read texts and emails and Facebook posts throughout the day. They are certainly reading. However, they no longer report reading much literature as part of their reading for pleasure. Developing role-plays based on "pre-texts" (O’Neill 1995) allows students to make literature visual. It is up to lecturers to act as "facilitators" in this creative learning context (ibid 83) providing "imaginative methodology" (Schewe 1998: 220).

Role-play can be seen to occur when someone acts out a role that is different from his/her normal role in order to create a piece of drama (O'Sullivan 2011: 512; O'Neill 1995: 78). Role-play involves "physicalization" as learning is given a physical form (Spolin 1973: 15; Schewe 1993: 8).

The GA2019 module I am concerned with here deals with storytelling, both folkloric storytelling and the modern short story. In Ireland, the storytelling that took place before the invention of radio and television was done in public (Ó Cadhla 2011 and Ó Giolláin 2005). Drama like role-play is public. Students can come to appreciate the storyteller's role more fully through role-play. Manfred Schewe's idea of "physicalization" of the learning is very relevant here. Role-play helps students to grasp the nature of storytelling by making the telling of the story that they have read visual.

As teachers and lecturers we constantly assess students (Baxter Magolda 2000) but educationalists rarely listen to what students think of their own learning. In my research I set out to listen to the student voice. I wanted to know whether or not they thought they were learning from preparing and performing role-play in the lectures.

In my research, I drew from the theory known as Teaching for Understanding (TfU). David Perkins maintains that the teacher has to organise "performances of understanding" that will allow the students to progress over time (Wiske 1998). Role-play, the focus group and the Classroom Assessment Techniques (CATs) (Angelo and Cross 1993) allowed the students "to think and act flexibly with what one knows", to quote Perkins (Wiske 1998: 40). CATs are quick 
and easily administered class exercises which allow students to explore a single question posed by their lecturer.

Stephen Krashen has written about the need to keep the Affective Filter as low as possible when teaching and particularly when teaching a language (Krashen 1982). Lowering the fear levels in class allows students to learn more. The Affective Filter is important, I would argue, in any class but is especially so where role-play forms part of the teaching methodology because students can feel very self-conscious when performing before the rest of the class. This is why it is so necessary for students to feel that they are working in a "safe space" in order to be able to take part in role-play successfully (Gayle et al. 2013). Other authors have questioned the existence of "safe space" especially in the classroom (Stengel \& Weems 2010). When doing role-play, there is always the danger that students will be laughed at or criticised by their classmates. I did not allow students to record the role-plays on their phones. I was also vigilant in monitoring how students were behaving in class. There were no problems on this score. The entire group was harmonious throughout. Every member of the class took part in the role-play. I took part in one role-play.

Role-play usually implies group work. I drew on Blatchford et al. (2003) and Long \& Porter (1985) in their analysis of group work. I will describe the importance of group work in the classroom in this article. Group work was central from the start in my students' use of role-play.

I consider role-play to be a worthwhile teaching and learning method. I researched how the students felt about it and whether they thought they were learning from it.

\section{Methodology: story - CAT - group work - role-play - questionnaire}

The main learning objectives of this module were concerned with the students learning to pick out the main themes of the stories and learning to portray these themes in the form of role-play. Our first step in class was to read a folkloric or modern short story. This functioned as a pre-text for the role-play. The next step was for the students to write a CAT on a possible role-play that they would like to perform based on the theme of that story. The CATs were written by the students in isolation without conferring with other students. Then the students were put into drama groups and together they worked on a role-play; sometimes they drew on the ideas expounded in the CATs, but usually they came up with new ideas in their groups. After 10-15 minutes of group work they performed the role-plays for the whole class. The group work proved transformative because even students who could not come up with any idea for a role-play on their own (as evidenced by the CATs they wrote) were able to devise a role-play while working in a group ${ }^{2}$. After the role-plays they filled in

\footnotetext{
${ }^{2}$ I have become fascinated by group work theory and am currently embarking on a new piece of research which will investigate the effects of group work on students' willingness to
} 
questionnaires that I had designed, which focused on the students' experience of doing role-play. These questions were concerned with how students felt before, during and after the role-play; how the group work had progressed; what they had learned from doing the role-play. This process was repeated three times during the course of the semester. On the first and second days of the semester, I introduced the idea of role-play to my students and told them that I was doing research on the use of role-play in literature lectures. The students seemed interested in what I was doing and when I gave them consent forms to sign, in which they agreed to take part in role-play and to have their photographs taken during class and to have their role-plays videotaped, all the students signed the form. In the sixth week of the semester I held a focus group in which I probed the students' assessment of the learning involved in role-play. In the tenth week of the semester the students submitted their essays which contained a section on role-play. I examined all of the data generated by the CATs, questionnaires, focus group and essays according to "Thematic Analysis" (Norton 2009). The main idea behind Thematic Analysis is that the researcher reads through the data looking for recurring themes suggested by the data. I engaged in this research technique from the beginning of my project.

\section{Role-Play on an Aesop's Fable}

One of the role-plays the students performed was based on an Aesop's fable called The Cock and the Fox. I have chosen to write about this role-play here because it was a particularly interesting example of the students' work. A large group of students was involved and they managed to execute the role-play with skill. The moral of the story is: "The best liars often get caught in their own lies" (Aesop 1994: 63f). In Aesop's fable, the fox tries to fool the cock into coming down from a tall tree. He tells a lie about a peace treaty among the animals, ensuring him that no harm will come to him. The cock sees through the fabrication and tells him that a pack of hounds are coming towards them. The fox abandons his story of the peace treaty and takes to his heels. The students in the role-play focus on the fact of getting caught out in a lie. They were not distracted by the detail of the fable and theirs was a loose application of the story. The students were given about 15 minutes to prepare the role-play.

Here I will translate the dialogue of this role-play. There were two groups of students on the stage: one young man and two young women per group. The three students on the right of the stage began a conversation which cannot be heard by the group on the left.

Young woman: Peter, were you out last night?

Peter: I was and Tom was there and he was talking shite. I hit him and he fell to the ground. The ambulance came and they went to hospital. I

speak in Irish to each other. 
went home with his girlfriend... so... (posturing and facial expressions to show that he was very happy with himself).

Young woman: Are you alright?

Peter: I'm fine but you should see Tom... (more posturing to show that Tom is in bad shape).

The two young women walk over to the other group on stage leaving Peter alone.

Young woman from Peter's group: Hello.

Young woman from second group: Hello.

Young woman from Peter's group: Tom, are you ok? We heard that you were in hospital because Peter hit you.

Tom: He’s lying. Nothing happened.

Young woman from Tom's group: We were with him all evening. Peter wasn't even there.

Young woman from Peter's group: Oh, my God!

Tom: Where is Peter?

Young woman from Peter's group: Oh, we don't know.

Tom: I see him.

Tom goes across the stage to Peter.

Tom: Peter! What were you talking about? Were you telling lies?

Tom attacks Peter.

Peter turns to the audience and says: That's it.

\section{Analysis of the role-play of Aesop's Fable}

The students' stage directions to each other were very clear and well executed. They had performed the role-play the previous week when it was recorded on a digital recorder. I, for one, had not understood what was happening the first time I saw this role-play. The dialogue was not clear and it was not well organised. The second attempt, when it was videotaped, was much better.

The male students in this role-play used their own names, which I have changed, when acting out the role-play. The female students did not address 
each other by name. There were thus only two clear characters - Peter and Tom - the young women functioned to carry the lie from Peter's to Tom's camp. The dialogue was loud and clear. There was no murmuring group as there had been in some other role-plays done by the students. The students came across as confident. Not all of the students on stage spoke, however.

The theme of this modern day story, no longer a fable, is that liars will be caught out and severely punished. The punishment here is immediate and similar in kind to the punch described in the original lie. Fight scenes tend to be popular in the students' role-plays and the students seem to find action scenes easier to portray than prolonged dialogue.

Although the role-play was performed in the Irish language, Peter uses Hiberno-English very effectively at the start of the role-play when he is describing Tom's supposed behaviour the previous night. He says that Tom was "ag caint shite" - talking shite! "Shite" is a derivation from the word "shit" but it is much more expressive when lengthened and is often lengthened in this way in Ireland.

Being able to take an Aesop's fable and apply it to a modern day situation was handled well by the students as evidenced by the positive audience response. Both the role-play itself and what students later wrote in their essays proved to be performances of understanding, i.e. the students showed their understanding through the performance. In the Aesop role-play, students illustrated that they understood the theme of the story and could adapt it to a modern day context. Writing about role-play in their essays proved a very necessary part of the learning process. I will deal briefly with these essays in this paper.

\section{Role-play on Sochraid Neil}

The following role-play was inspired by a short story which contains elements of both the oral tradition of storytelling and the modern short story. The story was written by Donncha Ó Céileachair and the action is set in the 1830's in West Cork. The plot of the original story is quite complicated. A young woman called Neil dies in childbirth. A fight ensues between her own family and her husband's family as to where they should bury her. Because she died in childbirth, her status is uncertain. A conflict arises because it is unclear in this society whether she is a girl who rightly belongs to her father and should, therefore, be buried with his people or a woman who belongs to her husband and should be buried with her husband's people as she has not completed the rite of passage (Riggs 1996: 138). The students were instructed to recreate the turning point of the story. The turning point of this story was the point at which her father, Conchubhar, having been victorious over his son-in-law, Muirtí Óg, hands over the coffin back to him and tells him he can bury her in his family graveyard if he wants to. Although the old world, Conchubhar's world, has been victorious, Conchubhar is wise enough to understand that the old ways must give way to the new.

The following role-play was performed by two students, a young man and 
a young woman. The role-play began with the female student, Muirtí Óg, carrying a small white lunch box across the stage. This box represented Neil's coffin which I, for one, thought ingenious. The male student playing the part of Conchubhar, who had positioned himself at the top of the steps to the left of the lecture theatre before the action began, came charging down the steps shouting and waving a long stick:

Young man: Give her to me!

He mimes striking the young woman with the stick. She bends over in supposed pain. She surrenders the coffin/box to him. The young man walks in a dignified manner with the box and the young woman follows behind. He then holds up a piece of paper to the audience which says "Reilig Bhaile Bhúirne"- Baile Mhúirne Cemetery. Both he and the audience laugh a little (perhaps because holding up a piece of paper in the middle of a roleplay seemed strange). He then turns to the young woman and says in a quiet voice:

Young man: Ye can take the corpse now if ye like.

He puts the "coffin" on the floor.

Young woman: Take the corpse? We're exhausted. We can't take the corpse.

Then the young man calls on his own "men", three female students from the audience. These students immediately come onto the stage and carry the box to the exit, followed by the two main characters.

\section{Analysis of Role-Play on Sochraid Neil}

The section of the story performed in the role-play above, the climax, was a very complicated passage in the story. There were references to different graveyards and it was not always clear which direction the coffin was being carried in. The Irish was also quite difficult. In contrast, the role-play was very stripped down and effective. The use of silence lent the scene solemnity. The two actors stayed in character throughout. The students had no time to rehearse the role-play within the space of the lecture theatre and yet they had foreseen everything perfectly. I found this role-play very moving. It was dramatic and compelling. The dignity of death was clearly evoked by the role-play. The only break in the tension was when the young man held up the piece of paper saying "Reilig Bhaile Bhúirne" and everyone laughed.

In the end of semester exam, there was no confusion regarding the events at the climax of this story. It seems that the simplified version enacted by the students served to clarify the sequence of events in the students' minds. All of the students in the class showed that they understood what was going on in the story. 


\section{Role-Play versus freeze frame}

I used a freeze frame with some of my students in the GA2019 module mainly for the purpose of taking a photograph of a particular scene. The fight scene in Bullaí Mhártain, also written by Donncha Ó Céileachair, is particularly complicated, so I chose this as the subject of the freeze frame. I thought if I could just slow down the action to a particular shot, the students would see who was doing what to whom. Although I carefully set the scene for this freeze frame myself, placing each student in their spot on the stage, it was a total disaster. The scene is complex to begin with. The scene is set in a dance hall. Various couples are dancing. A medical student is dancing with a local girl, Áine Bheití. A man, Pádraig Fada, who is the sworn enemy of Bullaí Mhártain, the hero or anti-hero of the story, tries to interrupt the dancing couple because he wants to dance with Áine Bheití himself. Bullaí Mhártain sees this attempt and begins to fight with Pádraig Fada. Bullaí Mhártain gets the better of Pádraig Fada and is pounding him while Pádraig Fada lies on the floor. Another man, whom we don't know by name, comes from the side lines and hits Bullaí Mhártain on the head with a bottle. Bullaí Mhártain falls to ground. He will not survive the resulting wound, we are later told.

While doing the freeze frame, it seemed perfectly clear who was doing what. In the exam, it was literally a different story. Many students thought that Pádraig Fada had killed Bullaí Mhártain. It is a notoriously difficult passage in the text. But the freeze frame didn't help matters. A role-play containing all the main characters might have been more effective. A very short role-play had been attempted by two students but it did not clarify the scene and focused only on the blow to Bullai's head. In future I will let the students organise the entire scene themselves. It is in working through the story in their groups that the students make sense of things. By trying to organise it for them in the freeze frame, I did not help them to understand it and by allowing a group consisting of only two students to attempt it, the opportunity to explore the scene fully was lost.

I wanted to investigate if the students felt that they were learning from doing role-play. To this end I carried out a focus group with four students. All of the students in the focus group had been involved in the role-plays that were performed in the lectures.

\section{Focus Group on Role-Play}

The focus group I carried out with four students took place after class in the sixth week of the semester (the half way mark). There was a good deal of ambivalence on the part of the participants in the focus group as to what they were learning from doing role-play. Two students reported that everyone could understand the story in a different way after doing role-play ((032/FG1/9); (035/FG1/9)). Role-play's facility to accommodate different perspectives had been noted by the students from the beginning of the research. All the students 
were "in the same boat", according to one student, and that it was more fun than work (034/FG1/9). Students seemed to feel that the classroom was functioning as a "safe space". This student does not see role-play as work (034/FG1/9) and according to student (032/FG1/5), the class may not even qualify as a formal lecture:

„We got on very well. I met people I didn't know before and I made friends that I wouldn't have made if we had lectures, ordinary lectures. So, it was very good." (032/FG1/5)

Given that the students were enjoying themselves, our sessions were neither lectures nor work. I asked the students if they would prefer not to continue with role-play in the lecture. No student wanted this. One student said:

"No. The start of the class is very good to just take a break from ordinary lectures where you are sitting for an hour listening to someone talking. It is much better to meet new people and to make friends, to do something different, to do something funny. I want to do it." (032/FG1/10)

The most striking thing about this statement is that the students wanted diversity in teaching methods. They wanted a break from the "ordinary lectures".

Another student agreed with this (033/FG1/10). However, student (034/FG1/10) did notwish to have role-play everyweek. Student (035/FG1/10) was extremely positive about role-play and said: "It gives us a break but it motivates us too to get into the stories and that. It is a wonderful thing, I think." (035/FG1/10) I decided to ask them a question that was not on my list: "It is worth doing role-play because you learn $\mathrm{X}$ from it. What is $\mathrm{X}$ ?"

"At the start you learn that the story is universal but after that it is the same thing. All the stories are... It is the same thing in all the stories. I don't know if you learn much from it but still it is something different. I think you remember the story for longer... because you did the roleplay and you will remember it and then you will have the original story." (032/FG1/13)

Another student said that the stories appeared relevant to today's world as a result of doing role-play and were not outmoded stories (033/FG1/13). We had made this point in class regarding the stories of Aesop. Another student maintained that one learns self-confidence from the role-play; however, even though they were doing something different every week, the characteristics of the stories were the same. In spite of this, she thought that it was a very good way to get into the stories and to learn the stories properly. (034/FG1/13) The first and second role-plays were dealing with fables. The students seemed to associate the "learning" here with the moral of the fable. Once you know the message being communicated by the story, that's all there is to it, or so it seemed to some students. One student argued against this idea by saying that the role-play motivated the students to read the stories $(035 / \mathrm{FG} 1 / 13)$. This is a very important reason for doing role-play in class, as reading literature is no 
longer popular among students. It is under threat from many other sources of information (Schewe 2004: 82). The same student also said:

"As well as that it is much easier to do this [role-play] and to learn the theme and to discuss it than... to be in the library on your own reading a difficult story and saying "What is the most important theme here?" In the group you have to perform it in front of the class and I think myself at any rate that it is much easier to discuss themes and things when we are preparing for the role-play." (035/FG1/13)

\section{CAT on Learning}

The ambivalence surrounding the learning associated with role-play surprised me and I was not sure how to proceed. It occurred to me that the problem may have been that the students did not know how to analyse their learning. I decided to carry out a CAT. The next week I asked the following question: What is learning? The students wrote their answers on a piece of paper and I collected these. I carefully read their answers after the lecture and I was heartened by what emerged.

Learning content was important for four students who maintained that learning was learning a new piece of information ((040/CAT2b); (042/CAT2b); (044/CAT2b); (047/CAT2b)). "You are learning when you are taking in new information" (042/CAT2b). It is, therefore, easy to understand why the students couldn't identify any new learning when they performed the second role-play the second time. As far as they could see, there wasn't any "new information" here. Given the preponderance of rote learning in the Irish education system, it was not surprising that for some students learning constituted learning things by heart and being able to reproduce them in an exam situation:

„I am not sure but I think that it is when you remember something that happened or that you heard in the class or lecture. And you are able to write that information on a page or in the exam." (043/CAT2b)

Memorization was mentioned by three students in relation to learning ((036/CAT2b); 043/CAT2b); 047/CAT2b)). However, one student emphasized the importance of understanding in the learning process:

„This is a very difficult question. I believe that it means getting to grips with things so that you understand them. If you learn things by heart, this is not real learning. You should be able to understand things, discuss them, create your own opinions and develop them. I believe that learning influences people, it changes the way they look at things... It has to do with understanding, if you are learning you will be able to understand things, new themes and concepts and to create your own ideas and to develop them." (039/CAT2b)

This student's description of learning reminds me of the theories associated with TfU; the student had no direct exposure to these theories. This student 
also sees learning as active. Another student also had a deep understanding of what could be classified as learning:

"Sometimes 'learning' is something that happens when a person's attitude changes, when something in the person changes. Something that forces you to continue your life in a different way." (038/CAT2b)

Learning was seen as an active process by two other students also: "It is easier to learn something when you do it rather than when you read about it from a book or listen to a teacher..." (041/CAT2b) Doing things physically, "physicalization" of the learning (Spolin 1973: 15; Schewe 1993: 8), results in students learning more directly and more effectively.

One student demonstrated that understanding of content occurs when one is able to discuss the topic studied with peers: “... I think you have learned something when you are able to talk about it, if you can give your opinion about it and discuss it with other people" (037/CATb). The opinions of some of these students (039/CAT2b; 038/CAT2b; 041/CAT2b; 037/CAT2b) are very close to David Perkins' theory of understanding: "understanding is the ability to think and act flexibly with what one knows" (Wiske 1998: 40). This was an unforeseen outcome of my research with role-play. Many of my students intend becoming teachers after their degree. They seem to have latched on to role-play as a teaching methodology and to have understood the implications for their own learning and also their own future teaching. I was delighted with this result.

\section{Students' Assessed Essays}

The essays were due in the tenth week of the semester and they contained a section on role-play that was obligatory. In this section students were required to discuss the learning that they associated with role-play. The essay mark was worth $50 \%$ of the overall mark for the module. One could argue that these marks encouraged the students to write about role-play in a positive light. Students signed their essays. It comes as no surprise, perhaps, that all of the students claimed to have learned something from doing role-play: students reported learning the themes of the stories; they said that role-play helped them to remember the stories better; they valued the social aspect of role-play and the new friends they had made through the group work involved in role-play; they reported understanding the process involved in storytelling better on account of role-play. I am inclined to believe their claims that they had indeed learned various things from doing role-play. Thinking about learning in the CAT on learning may also have helped the students to gain a wider and deeper idea of what constituted learning. Writing about the experience of doing role-play as part of the essays helped students to reflect on that experience at their leisure. The CATs and questionnaires were written at speed in class and the focus group was also a fairly rapid affair. In the essays, the students had time to look at 
the whole process involved in role-play and to take stock. The conclusions the students came to were overwhelmingly positive. I have written at some length on the subject of the students' essays in another publication (Ní Riain 2017).

\section{Module Evaluation}

In the third questionnaire, the students were extremely positive in their remarks regarding role-play. This questionnaire also functioned as a module evaluation. The questionnaire was anonymous. There were only 12 students present in the final class when the evaluation took place. 11/12 students reported that the module was "very good" and 1/12 reported that it was "fairly good." The students were very positive about the whole role-play experience. Here is a small sample of what they said:

- "I look forward to the class every week because we have to do something in the class and I don't feel tired." (074/Q3/11)

- "Without any doubt, the best module!!! Every lecture was very interesting." (076/Q3/12)

- "We did all the work, we analysed each story but we still had fun!" (077/Q3/11)

\section{Offering of GA2019}

Given the success I had had with role-play in 2015, I decided to use role-play once again the following year in my GA2019 module. This time the reaction to role-play was very different. Some male students refused to sign the consent form and others, who had already signed it, followed their lead and refused to get involved in role-play. I was dismayed at this response. I had to reconsider using role-play in the lectures. I recognise from my experiences with role-play in other settings that role-play can awaken feelings of anxiety in some students. Role-play does not suit every student. I did not want to give up, however, so I adapted my use of it to accommodate the students' position.

After reading a pre-text, I got students to write a scenario and dialogue in small groups. So far so good. I then asked them to read out the parts while sitting in their chairs. They did this, and judging from the expressions on their faces, enjoyed the experience very much. I did not push them to perform standing in front of the class. It may not have been role-play in the normal sense, but the students got some experience of role-play on their own terms. In the student feedback form at the end of the semester, I was surprised that so many of the students seemed to enjoy role-play, albeit a very modified version of role-play.

I concluded from this experience with role-play that it will not suit all groups of students and may need to be adapted to be acceptable at all to some groups. 
Listening to the student voice does require the teacher/lecturer to take what the students are saying on board.

\section{Conclusion}

Based on my research in 2015-2016, I can conclude that role-play takes time to grow on students and may not be accepted at all if presented in a rigid form. Some groups of students enjoy role-play immensely, but individual students may have serious anxiety issues around performing in front of the class. My advice to teachers and lecturers who would like to try out role-play in literature classes/lectures is to listen to the students and to adapt role-play where necessary to the students' needs. The data generated from my research tools suggests that students do associate many different types of learning with role-play. There was, however, no consensus on what exactly could be learned from role-play.

Acknowledgements - I would like to thank the following people for their help and support during my research: Prof. Pádraig Ó Macháin (UCC), Prof. Manfred Schewe (UCC), and Prof. Louise Ryan (University of Sheffield). I am very grateful to all the team at CIRTL (UCC) for their help and inspiration throughout my teaching and learning studies. I would also like to thank the reviewers of this article for their helpful advice. Finally, I am extremely grateful to my students for participating in this research project.

\section{Bibliography}

Aesop's Fables (1994): London: Bloomsbury Books (Children's Classics) Almqvist, Bo \& Ó Cathasaigh, Roibeard (eds.) (2010): Ó Bhéal an Bhab Cnuas-scéalta Bhab Feiritéar. Conamara: Cló Iar-Chonnacht

Angelo, Thomas A. \& Cross, K. Patricia (1993): Classroom Assessment Techniques: A Handbook for College Teachers ( $2^{\text {nd }}$ ed.). San Francisco, CA: Jossey-Bass

Baxter Magolda, Macia B. (2000). Teaching to Promote Holistic Learning and Development. In: New Directions for Teaching and Learning 82, 88-98 http://jan.ucc.nau.edu/ coesyl-p/principle9-article2.pdf (last accessed Dec 10, 2015)

Blatchford, Peter; Kutnick, Peter; Baines, Ed \& Galton, Maurice (2003): Toward a social pedagogy of classroom group work. In: International Journal of Educational Research 39, 153-172. http://eprints.ioe.ac.uk/1197/1/Blatchford2003Toward153.pdf (last accessed Dec 6, 2015)

Cohen, Louis \& Manion, Lawrence (1994): Research Methods in Education. London: Routledge 
Gayle, Barbara Mae; Cortez, Derek \& Press, Raymond W. (2013): Safe Spaces, Difficult Dialogues, and Critical Thinking. In: International Journal for the Scholarship of Teaching and Learning 7/2, 1-8.

http://digitalcommons.georgiasouthern.edu/ij-sotl/vol7/iss2/5 (last accessed Dec 10, 2015)

Gerber, Ulrich (1990): Literary Role Play. In: ELT Journal 44/1, 199-203. http://203.72.145.166/ELT/files/44-3-4.pdf (last accessed June 30, 2015)

Gibbons, Pauline (2002): Scaffolding Language - Scaffolding Learning: Teaching Second Language Learners in the Mainstream Classroom. Portsmouth, NH: Heinemann

Heathcote, Dorothy (1995): Drama for Learning. Portsmouth, NH: Heinemann

Hitchcock, Graham \& Hughes, David (1995): Researcher and the Teacher - A Qualitative Introduction to School-based Research (2 ${ }^{\text {nd }}$ ed.). London: Routledge

Kennedy, Declan (2007): Writing and Using Learning Outcomes: a practical guide. Cork: University College Cork

Long, Michael H. \& Porter, Patricia A. (1985): Group Work, Interlanguage Talk, and Second Language Acquisition. In: TESOL Quarterly 19/2, 207-228 http://course1.winona.edu/hshi/documents/groupwork interlanguagetalkandl2acquisition.pdf (last accessed Dec 10, 2015)

Mettetal, Gwendolyn (2002): The What, Why and How of Classroom Action Research. In: Journal of the Scholarship of Teaching and Learning 2/1, 7-13 http://josotl.indiana.edu/article/view/1589/1588 (last accessed June 12, 2015)

Neelands, Jonothan and Tony Goode (1995): Structuring Drama Work: A Handbook of Available Forms in Theatre and Drama. . Cambridge: Cambridge University Press

Neelands, Jonothan (1987): Making Sense of Drama: A Guide to Classroom Practice. London: Heinemann Educational Books Ltd.

Ní Riain, Isobel (2017): Modhanna Múinte Gaeilge: An Ról-imirt. Baile Átha Cliath: Coiscéim

Ní Riain, Isobel (2014): Drama in the Language Lab - Goffman to the rescue. In: Scenario VIII/2, 115-123

Norton, Lin (2009): Action Research in Teaching and Learning: A Practical Guide to Conducting Pedagogical Research in Universities. London: Routledge

O'Brien, Rory (1998): An Overview of the Methodological Approach of Action Research. In: Roberto Richardson (ed.): Theory and Practice of Action Research. Brazil: Universidade Federal da Paraíba. (English version available online) . http://www.web.ca/ robrien/papers/arfinal.html (last accessed: 10/12/15)

Ó Cadhla, Stiofán (2011): An tSlat Féithleoige - Ealaíona an Dúchais 1800-2000. Conamara: Cló Iar-Chonnacht 
Ó Giolláin, Diarmuid (2005): An Dúchas agus an Domhan. Cork: Cork University Press

O’Neill, Cecily (1995): Drama Worlds: A Framework For Process Drama. Portsmouth, NH: Heinemann

O'Sullivan, Carmel (2011): Role-playing. In: Cohen, Louis; Manion, Lawrence \& Morrison, Keith (eds.): Research Methods in Education ( $7^{\text {th }}$ ed.). London: Routledge, 510-527

Riggs, Pádraigín (1996). Imaginary Heroes: A New Look at the Representation of the Heroic in Two Stories by the Gaelic Writer Donncha Ó Céileachair (1918-1960). In: Logez-Carpentier, Godeleine (ed.): L'Irlande: Imaginaire et Représentaion. Lille: Actes du Colloque de la SOFEIR, 135-142

Schewe, Manfred (1998):Culture through literature through drama. In: Byram, Michael \& Fleming, Michael (eds.): Language Learning in Intercultural Perspective: Approaches through drama and ethnography. Cambridge: Cambridge University Press, 204-221

Schewe, Manfred \& Beug, Joachim (1997): Seeing the dragons dance together on the wind at sunset... An aesthetic approach to understanding another culture. In: fsu 41/50, 418-422

Schewe, Manfred \& Scott, Trina (2003): Literatur verstehen und inszenieren Foreign Language Literature Through Drama. A Research Project. In: GFL-Journal 3, 56-83

Schewe, Manfred \& Shaw, Peter (eds.) (1993): Towards Drama as a Method in the Foreign Language Classroom. Frankfurt am Main: Peter Lang

Spolin, Viola (1973): Improvisation for the Theatre - A Handbook of Teaching and Directing Techniques. London: Pitman and Sons Ltd.

Stengel, Barbara S. \& Weems, Lisa (2010): Questioning Safe Space: An Introduction. In: Studies in Philosophy and Education 29, 505-507 (DOI 10.1007/s11217-010-9205-8). http://www . academia.edu/2767383/ Questioning_Safe_Space_An_Introduction (last accessed May 29, 2014)

Sweeney, Catherine; O'Sullivan, Eleanor \& McCarthy, Marian (2015): Keeping it real: Exploring an interdisciplinary breaking bad news role-play as an integrative learning opportunity. In: Journal of the Scholarship of Teaching and Learning 15/2, 14-32

http://josotl.indiana.edu/article/view/13262/20182 (last accessed Dec 16, 2015)

Thomas, Gary (2013). How To Do Your Research Project. London: Sage

Wiske, Martha Stone (ed.) (1998): Teaching for Understanding - Linking Research with Practice. San Francisco: Jossey-Bass 